\title{
CONCERNS ABOUT HAMONIZATION PROCESS OF SERBIAN AGRICULTURAL POLICY WITH EU STANDARDS
}

\author{
Nina Maksimović Sekulić ${ }^{1}$, Jovan Živadinović2 ${ }^{2}$ Ljiljana Dimitrijević3 \\ *Corresponding author E-mail: nina.maksimovicbg@gmail.com
}

A R T I C L E I N F O
Review Article
Received: 01 December 2018
Accepted: 17 December 2018
doi:10.5937/ekoPolj1804627M
UDC 338.43.01/.02(497.11:4-672EU)

Keywords:

Common Agricultural Policy (CAP), Chapter 11, Agriculture and rural development, Agricultural Policy, EU accession.

JEL: Q18, K39

\section{A B S T R A C T}

Common agricultural policy (CAP) is the most dynamic segment of the EU legal legacy and the driving force of integration. The role and significance of this sector in the EU's overall economy is to ensure the health of the population, rural development and environmental protection. Agricultural policy has emerged because of longstanding discussions about the need for the national agricultural policies of the countries of Western Europe to harmonize with each other, in order to ensure additional supply of food to the European population after World War II. Because of the exceptional importance of agriculture for economic stability and sustainable development, harmonization national policies with EU Common Agricultural Policy are essential. The specificities of national agriculture must be adequately respected in the legal and institutional arrangements that the country will adopt and apply in the EU accession process; otherwise, there would be deep and far-reaching consequences for those parts of national agribusiness that cannot fulfill the EU requirements. In this paper, throw the analytical and comparative method will be discussed the EU standards in this area, the harmonization level of Serbian agricultural policy with EU standards with special emphasis on negotiating chapter 11 and the institutional and legislative constraints in the EU accession process.

(C) 2018 EA. All rights reserved.

1 Nina Maksimović Sekulić, Ph.D., Assistant professor, Modern business school Belgrade, st. Terazije num. 27, 11000 Belgrade, Serbia, tel num: +38162 206 642, Email: nina. maksimovicbg@gmail.com

2 Jovan Živadinović, Ph.D., Professor, High School for Business Economics and Entrepreneurship in Belgrade, Mitropolita Petra 8, 11000 Belgrade, Serbia, phone: +381 63 10702 12; E-mail: jovan.zivadinovic@vspep.edu.rs

3 Ljiljana Dimitrijevic, Ph.D., Assistant professor, High School for Business Economics and Entrepreneurship in Belgrade, Mitropolita Petra 8, 11000 Belgrade, Serbia, phone. +381 64 1388 474; E-mail: ljsrecka3014@gmail.com 


\section{Introduction}

Starting from the fact that the agricultural sector and rural development in the European Union are regulated by a common policy, adapting this policy is a particularly challenging area in the integration process. First, it should be noted that this policy is one of the oldest EU policies. Common rules must meet the different needs of many countries. Common agricultural policy has influenced: increasing agricultural production and productivity, changing the production structure, stabilizing the internal market, increasing exports, importing independence, protecting and increasing producer incomes, supply security, etc. (Babović i Tasić, 2013). Throughout history, CAP had several major reforms, primarily due to the criticism of the over-protection of agriculture (the prices on the domestic market were more than world prices) and too high a budget, which would be a burden for taxpayers. Since the end of the 1990s, reforms have been carried out due to the necessity of respecting the needs of the completely rural area, the protection of the environment and cultural heritage. (Mikuš et al, 2010)

The agricultural sector of Serbia faces with serious difficulties, and its recovery, economic growth and competitiveness of agricultural products, improvement of standards and preservation of the environment, are possible only with the integration and implementation of CPU regulations. In recent years, the Republic of Serbia has launched a process of structural and systemic agrarian reforms (Strategy for Agriculture and Rural Development for the period 2014-2024). Compliance with EU legislation in this area has been initiated with the help of financial programs (SAPARD, IPA, IPARD, etc.). One of the most complex chapters in EU accession negotiations is the Agriculture chapter, as more than one-third of all accession regulations are from this sector. The basic goals of the paper are to establish the current features of the EU Common Agricultural Policy, with a special emphasis on the future development plan, and the implications for the Republic of Serbia and the problems of adjusting EU agricultural policy.

\section{Methods of research and sources of data}

Based on the set goals, the analysis of the content of secondary data sources was used as the basic methods of research. Secondary data, information on the CAP history and its reforms were taken mostly from the official European Commission documents and relevant literature. The data on the state of the Serbian agrarian sector, as well as the current and potential problems that the RS faces on the basis of the literature on RS agricultural policy, strategic documents, Serbia's Progress Report on the Accession Process.

\section{Research results}

\section{CAP - Historical overview}

The common agricultural policy, established by the 1957 Treaty of Rome was the cornerstone of the then European Economic Community (EEC), consisting of France, Western Germany, Italy, the Netherlands, Belgium and Luxemburg. EEC in order to 
reduce the risk of food shortages (present immediately after World War II) progressively creates a common marcet, and article 39 of The Rome Treaty for the first time defines the aims of the CPA:

1) raising agricultural productivity by promoting technical progress, rational development of agricultural production and optimal use of production factors, in particular labor,

2) ensuring the standard of living for the agricultural population, in particular the raising of the income of persons who are personally engaged in agriculture,

3) market stabilization,

4) market security,

5) insurance of agricultural products for consumers at reasonable prices.

The policy was established 5 years after signing the contract, because many countries did not respond adequately and interested in a common policy. At the Conference, which was held in 1958, standards are being adopted and first steps are taken towards the implementation of a common agrarian policy. (Živadinović i Milovanović, 2011).

The three principles defined in 1962, on which the agrarian policy is based within the framework of the common organization of the single market, are:

1. Rules on the free movement of goods between member countries (regulation and determination of common price, grant of aid regardless of location of economic entity, implementation of administration and common foreign policy, etc.);

2. Determining the activities of the Union's priorities (prioritization of agricultural products from the Union in relation to those imported from third countries, protection of the internal market caused by disorders in the world and

low prices of imported products from third countries, etc.);

3. Principle of financial solidarity (strives that all costs incurred in the Union, through the application of agrarian policy, must be distributed to all Member States). The European Agricultural Guidance and Guarantee Fund was established in 1964 and financed the implementation of the CAP. (Mihajlović, 2011).

Radical proposals for policy reform have been framed within the framework of the Memorandum of CAP Reform, called the Mansholt's 1968 Collegiate Plan, with the emphasis on ensuring the support of farmers to stop dealing with agriculture during the 1970s and at least 5 million hectares by then of cultivated land excluded from production (Stead, 2007). However, no concrete reforms were carried out and in agriculture there was still a problem of continuously growing surpluses. Apart from the costs of storing surpluses and dumping, as a way to achieve greater and faster exports, there have been negative consequences of increased production for environmental protection (eg water pollution, depletion of soil). In 1988, a set aside measure was introduced to encourage 
farmers not to produce, in order to reduce market surpluses and restore the ecosystem. (Mikuš et al, 2010) From the 1980s to 1992, facing the European Union with high market surpluses and reducing aid to agrarian (attempt to reduce budgets).

Agricultue Directorate General - DG VI has prepared a paper with analyzes of problems and reform proposals. It was this reform called the MacSharry reform that marked a milestone in CAP development, as it proposed lowering the prices of agricultural and food products. The reform also proposed structural measures: early retirement incentives farmers who respect environmental protection in the production and afforestation incentives (Moyer, 1993). From 1992 to 2005, the CPU was based on the policy of direct payments and. increasingly, the policy of rural development (Mihajlović, 2011). This is a significant period for the Serbian agriculture, because then (from 2000 onwards) the first serious steps towards systemic and structural reform begin.

The Commission proposed a reform of the CAP, Agenda 2000, which also served as a basis for the development of EU agriculture in the period 2000-2006. Negotiations and agreement on reform of the CPA were concluded in 1999 in Berlin. With the marketpricing measures that made up the first pillar of the CPA, measures were also extended rural development and officially introduced the second pillar - rural development policy. Agenda 2000 was the most extensive reform ever in CAP history.

The reform envisioned: 1) to increase the competitiveness of agricultural products on the internal and global market, 2) to provide a decent living standard for people living in agriculture, 3) creating substitute jobs and other sources of income for farmers, 4) designing a new rural development policy, 5) an ecological way of thinking and structuring the CAP, 6) improving the quality and safety of food, and 7) simplification of agricultural legislation and decentralization administration, so that the rules and procedures become clear, transparent andeasy to use. (Mikuš et al, 2010)

Agriculture has a multinational role. The reform affects the reduction of surpluses and cost control. It affects the improvement of food safety and quality, environmental protection. An adequate training of farmers is carried out. The aim is to find alternatives for employment and new sources of income. The farmers receive direct assistance and subsidies from the funds: ERDF, ESF, EAGGF, FIFG. (Živadinović, Milovanović, 2011)

In 2003, the Member of the European Commission in charge of Agriculture, Franz Fischler, proposed a new Mid-Term Review, according to which existing direct payments, related to different production activities, were converted into a single payment per holding. In total support she prevailed income support, not support for production. The farmer has the right to support whatever the current one production activities but under certain conditions (cross-compliance): 1) preservation of good production condition of the land, 2) Treatment in accordance with environmental protection requirements (protection of wild birds, pollution of water and soil, natural habitats, eco-systems), 3) treatment in accordance with the requirements of human and animal health protection (eg livestock marking, food safety), 4) compliance with requirements animal welfare, 5) placement of land out of use for areas under cereals, 6) areas under permanent pasture 
from 2003 are not allowed in the future to become arable land; and 7) certain products that have not been encouraged before, they must not produce on surfaces for which incentives can be generated (except under subsequently certain conditions).

The Health Check reform came into force in 2008, within the programming period (2007-2013). with the task of modernizing and simplifying the CAP, i.e. allowing better responses to new challenges and opportunities facing European farmers.

At its last plenary session in 2017, the European Parliament adopted a legislative resolution that makes the European Union's agricultural policy more straightforward and fairer. The rules adopted will simplify the EU's agricultural policy, strengthen the negotiating power of farmers in relation to retail chains, and better equip them to cope with the risks. The CAP reform, which came into force in 2018, was adopted with 503 votes in favor, 87 against and 13 abstentions. The new rules should strengthen the negotiating power of farmers, allowing all recognized agricultural organizations to plan production and negotiate contracts for the procurement of goods on behalf of their members, without violating EU competition rules. Collections have so far been permitted only in several sectors, such as the dairy sector, the olive oil sector, beef and cereals. Farmers will also be better protected against market volatility and crises, such as bad weather conditions, plant pests or animal diseases. The European Commission will be empowered to react more quickly to crises, with extraordinary measures to support farmers. Young farmers will be eligible for full five years of enjoying the status of young farmers after the resolution enters into force. Member States will have greater flexibility in defining "active farmers", ie, a person entitled to EU subsidizing agricultural holdings. They could also significantly increase additional funding, from $25 \%$ to $50 \%$ of their basic payments for the first $25-90$ hectares, for young farmers, to attract them into the agricultural sector.

\section{Implications of rural development policy to the Western Balkans countries}

In 1989, the European Commission set up guidelines relating to the preparation of the countries of Central and Eastern Europe for membership of the Union, which were later integrated into the IPA program, namely:

- PHARE (Program of Community aid to the countries of Central and Eastern Europe). Aid for investment and project management, administrative reform, economic and social cohesion of candidates

- ISPA (International Sleep Products Association). A program designed to build infrastructure for transportation, environmental protection;

- CARDS (Community Assistance for Reconstruction, Development and Stabilization). The program referred to the period from 2000 to 2006 and was aimed at the countries of the Western Balkans, the rebuilding of the region, the reduction of poverty, market reform, interregional cooperation, etc. (Živadinović, Milovanović, 2011). 
- Program SAPARD (Special Accession Program for Agriculture and Rural Development) is the successor to PHARE. It was established by the Council of Europe in June 1999, the application of which came into force on January 1, 2000. The program was designed to help 10 Central and Eastern European countries to deal with the structural adjustment of agrarian law with EU regulations. It included investments in agricultural holdings and rural development. The program also referred to investment in landownership and improvement of land quality, afforestation, education and training of farmers, consumer protection, etc. SAPARD defines three priorities: to increase market efficiency; to accept standards on the quality of medical care due to the participation of candidates on the market; to support new jobs in rural areas. The EU has financed up to $75 \%$ of the project, and the rest is end users, contractors and private entrepreneurs. The aim was to enable potential candidates to become self-sufficient and to become independent in the management of funds, while not requiring prior approval by the European Commission).

There were a lot of challenges during program implementation. A large number of abuses were committed in the allocation of funds, and they usually ended up with developed farmers. For example, in Bulgaria and Romania, certificates were issued without a direct insight. In Poland, $48 \%$ of projects were rejected - due to incomplete documentation. (Stojanovic et all, 2018)

The three major problems of the candidate countries are:

-macroeconomic, a large influx of aid has triggered inflation and exchange rate volatility; -administrative, at all levels, timely acceptance of projects, coordination of partners and stakeholders, administration, financing and implementation of implementation, etc;

-financial capacities, i.e. the ability to fund programs and support from the EU, the growth of the budget deficit, liquidity (spending of own money, due to a subsequent refund.

By the Directive of the European Council, in 2006, an Instrument for Pre-Accession Assistance (IPA) was established. The program was intended to support candidate countries and potential candidates for the period 2007-2013. The Instrument for PreAccession Assistance was focused on two priorities: 1) that countries meet political and economic criteria, to adopt the acquis, to strengthen the judiciary, form administrative apparatus, etc;

2) The second priority was to use the EU structural and cohesion funds after accession. The European Union has provided targeted and effective support, depending on the realization of the development path and the status of accession to each candidate country. The condition for use was a status for membership and an accredited DIS by the European Commission. Funds were obtained based on a pre-planned and elaborated program for the implementation of priorities in EU strategic documents. According to the project cycle module, with five of its phases: programming, indication, formulation, implementation, evaluation and audit. 
The beneficiary countries were divided into two groups: candidates (Iceland, Turkey, Croatia and Macedonia) and potential candidates (Serbia, Montenegro, Bosnia and Herzegovina, Albania and Kosovo and Metohija).

The five components of the Instrument for Pre-Accession Assistance (IPA) were:

1) Component I-Aid to transition and institution building concerned: support for EU approximation in meeting criteria and standards, strengthening institutions, participation in Community programs and in the work of agencies, etc. The requirement for the project to be approved by the EC was that the goals be consistent with the Multi-annual Indicative Planning Document (MIPD) priorities, that the project is technically correct and in line with time frames, that there is an organizational unit for the implementation of the project, etc. The program allocated EUR 4.7 billion and was a direct nonrefundable EU financial grant.

2) Component II - Regional and cross-border cooperation concerned: strengthening cooperation through local and regional initiatives, sustainable economic and social development, improvement of the environment, development of entrepreneurship and tourism, facilitating regional trade, border management, improvement and implementation of laws, etc. Additional help was within the multi-annual project for each member or group

at the NUTS (Nomenclature des Unites Territoriales Statistiques) region for the period from 2007 to 2012. The EU allocated 350 million euros to candidate and potential members for membership at that time.

3) Component III-Rural Development refers to the financing of projects for technical assistance and investment works. The members received funds from the funds (ERDF, ESF and Cohesion Fund) in order to achieve three goals: convergence, regional competitiveness, employment and European territorial cooperation. From 2007 to 2012, this component could be used by Croatia, Macedonia and Turkey.

4) Component IV-related to Human Resources Development. The aim was economic and social cohesion, which was related to employment, education, training and social inclusion (only to member countries). The aid was provided in the form of guarantors and technical assistance.

5) Component V - Rural Development was intended for the development of villages in candidate countries for the implementation and management of the common agricultural policy of the EU. The preparation of the funds was used by the EAFRD - European Agricultural Fund for Rural Development. (Stojanovic et all, 2018)

IPA assistance in Serbia was initially not aimed to be long term development mechanism, but more as starting tool that will enable beneficiaries - institutions and farmers - to continue in right direction. Late start and slow process of reforms together with overall situation in the country, further weakened by global economic crisis, showed that longer assistance will be required in order to reach full harmonization with EU standards and requirements in agriculture sector (Vapa Tankosić, Stojsavljević, 2014) 


\section{Agricultural Policy of the Republic of Serbia in the European-integration Process}

Agriculture is one of the promising and important industries for Serbia. In recent years, it has lost its importance, under the influence of other industries, first of all industries, and today more and more of technology and technology, science and services. The development of agriculture and the implementation of the process depend on many social and economic factors, from the achieved level of development of production forces and production relations and their influence on the state and attitude in the agrarian sector (Nikolic and Mihajlovic, 2017).

Based on previous experience of other members, one of the toughest chapters in EU accession negotiations is the chapter on agriculture and rural development. The path that Serbia must get to receive in the EU and equal membership is full of challenges and difficulties. It brings many changes related to organization, system control, production, the establishment of European standards, etc. The EU's agricultural policy is in continuous development, rather complicated and subject to constant changes. It takes a lot of time and effort, good coordination about policy alignment. CPU regulations constitute more than one-third of all EU regulations. Therefore, the chapter on agriculture should focus on priorities, ie work on the implementation of all regulations related to the association of Serbian agricultural policy with the common agricultural policy of the EU.

The Ministry of Agriculture, Forestry and Water Management (MAFWM) has the largest role in the integration and accession of agriculture of Serbia and the EU. However, due to the seriousness and scope of work, other bodies and institutions need to be involved in cooperation: the Ministry of European Integration, the Ministry of Economy and Rural Development, the Ministry of Trade and Services, the Ministry of Health, the Chamber of Commerce, Universities, etc. (Stojanovic et al., 2018).

In the past period, there has been a lot of support and assistance that the EU has implemented and donated to Serbia on its way towards alignment with CAP standards and joining a community of European nations. Some of the important donors are: Austria, Germany, Czech Republic, Japan, Switzerland, Sweden, etc. The Norwegian government has allocated a million euros to help Serbia in the framework of the project "Improving the organization of agricultural cooperatives in Serbia under the Norwegian model in 2001". The aim was to improve the business of new and existing cooperatives and agricultural associations. The Danish government's project implemented in the period from 2010 to 2014 in the south of Serbia "Implementation of the program of the economic sector for support of fruit growing and the sector of breeding of gingerbread and berry fruit in the south of Serbia" referred to the technical assistance of support of 4 million euros and donation of 5 million euro. Partnership for revitalization of rural areas, the donation of the Romanian government from 2010 to 2011, has enabled a budget of 0.2 million euros for strengthening rural social capital and promoting rural development. Serbia had EUR 1.45 million for the SAPARD program (MAFWM, 2017). 
The agro-food sector and rural areas of Serbia are confronted with many challenges and problems, which reduce economic growth and development and hinder the Republic of Serbia on the path to equal membership in the EU. Therefore, for ten years, the Republic of Serbia implements the agricultural and rural development policy with the realization of: the Strategy of Agriculture and Rural Development of the Republic of Serbia for the period from 2014 to 2024, including two national programs for agriculture and rural development (MAFWE , 2014). rural development and institutions, organizations in the process of program implementation, etc. The way of functioning of the IPARD program is implemented through: the announcement of the competition and the public call, filling in the application forms, receiving and registering the project approval requests. After that, the process of acceptability of requests and users is checked (site control and administrative processing of control results). When scoring and ranking is performed, the decision and conclusion of the contract on the use of incentive funds from the IPARD program is made. (MAFWM, 2017).

It is necessary to emphasize the importance of IPARD (Instrument for Preaccession Assistance for Rural Development) program covering the period from 2014 to 2020. This is an aid instrument for rural development, achieving European standards and raising competitiveness. Serbia does not have enough competitive products (low efficiency, high costs, and unstable production conditions). Therefore, IPARD measures are trying to invest in development, in order to increase productivity. The objective of the IPARD program investment for Serbia relates to the restructuring and modernization of the agricultural food industry sector, harmonization with EU standards in food safety (veterinary, phytosanitary and ecological). The program should define support measures in accordance with current regulations, as well as the criteria and financial support frameworks, in line with EU regulations, to influence the strengthening of the LEADER approach. The structure of the program relates to SWOT, a detailed description of the measures and strategies of agriculture and rural development, the presentation of financial tables and the process of program communication, separation with national measures for rural development and institutions, organizations in the process of program implementation, etc. The way of functioning of the IPARD program is implemented through the announcement of the competition and the public call, filling in the application forms, receiving and registering the project approval requests. After that, the process of acceptability of requests and users is checked (site control and administrative processing of control results). When scoring and ranking is performed, the decision and the conclusion of the contract are made using incentive funds from the IPARD Program (MAFWE, 2017).

Serbia applied for admission to the European Union on December 22, 2009. The status of candidate for EU membership was granted to the European Council on March 1, 2012, while the decision to open accession negotiations with Serbia was made on June 28, The Republic of Serbia's EU membership talks officially began on January 21, 2014 in Brussels. For the area of agriculture, three chapters are directly related to chapter 11 (agriculture and rural development), chapter 12 (veterinary and phytosanitary policy and food safety), and 
chapter 13 (fisheries). Another chapter that is indirectly related to agriculture is Chapter 27 - Environment and Chapter 28 - Consumer and Health Protection. (EU notes, 2017)

The chapter on agriculture contains a large number of binding rules, the correct application of which is essential for the functioning of the CAP. CAP implementation requires the establishment of a management and quality system such as the paying agency and the Integrated Administration and Control System, as well as capacity to implement rural development measures. Member States must be able to apply EU rules to direct aid schemes to agricultural holdings and to establish common market organizations for different agricultural projects. Furthermore, it is necessary to emphasize what changes in Serbian agriculture will be needed to adapt to the conditions and rules that exist in the common European market. When it comes to European standards in agriculture, it is mainly thought of the Good Agricultural Practices (GAP). GAPs involve the application of knowledge in the use of natural resources on sustainable principles in order to produce safe, health-safe food and other agricultural products in a human manner and with the provision of economic viability and social stability.

In simple terms, it is necessary to know, understand, plan, measure, record, control and manage the production system in order to achieve determined production and ecological goals. Good Agricultural Practices (GAP) is based on the control of critical points (H.A.C.C.P.) and the quality of products given under the Codex Alimentarius Code of Practice of the World Health Organization. The World Food and Agriculture Organization (FAO) Good Agricultural Initiative (FAO) initiative provides a mechanism for the implementation of specific activities that enable sustainable agriculture and rural development. The methodology of good agricultural practice refers to specific production problems such as, for example, the use of integral protection methods and sustainable agriculture. Adherence to these standards should have a direct consequence of increasing the competitiveness of Serbian agriculture. However, in order for these standards to be truly accepted and practically implemented, there will be a need for a change in domestic legislation, the consistent application of adopted laws (which is currently not the case in Serbia), and most importantly - education and change of awareness of all those directly or indirectly involved in agricultural production.

According to Serbia progress report, Serbia has some level of preparation in agriculture and rural development. Good progress was made by achieving entrustment with budget implementation tasks for all the measures included in the IPARD II Programme and amending the law on agriculture and rural development. In the coming period, Serbia should in particular: implement the measures entrusted under the IPARD II programme and seek entrustment with budget implementation tasks for other measures of the programme; finalize and proceed with implementation of the action plan for acquis alignment in agriculture and rural development. As regards horizontal issues, the action plan for acquis alignment in agriculture and rural development still needs to be adopted. The National Program for Agriculture for the period 2018-2020 was adopted in 2017 while the program for rural development still needs to be adopted. A fully functional IPARD agency was established. The amendment to the law on agriculture and rural 
development established the legal basis for IPARD and also for the future Integrated Administration and Control System (IACS), which is yet to be developed. Further alignment with EU policies requires decoupling of payments from production and linkage of area based payments to cross-compliance standards. The Farm Accountancy Data Network (FADN) is established, formal institutional responsibilities designated, and aligning legislation has been adopted. Serbia has a farm advisory system in place. In the area of the common market organization (CMO), a number of implementing legal acts aiming at further alignment in the wine sector were adopted. Serbia should take steps towards aligning with the other elements of the $\mathrm{CMO}$, including sector specific schemes, marketing standards, support for public and private storage, marketing and producer organizations, market intervention. On rural development, Serbia has taken a significant step forward in being entrusted by the European Commission with budget implementation tasks for two investment measures under the IPARD II Programme. Serbia should focus on spending EU funds while, at the same time, prepare remaining IPARD measures for implementation in 2018. Progress is slow in the area of quality policy. Legislation in the area of agricultural products and foodstuffs needs to be aligned to facilitate policy development in this field. Legislation pertaining to quality wine products also needs to be fully aligned with the acquis. As regards organic farming, Serbia has established a competent authority for organic production, a system of accreditation of control bodies and a system of certification of organic production. Further alignment with the acquis on organic production is however needed. A national action plan for the development of the organic sector has yet to be adopted. (Serbia progress Report, 2018)

\section{Conclusions}

The CAP provides: access to safe and stable quality food products produced in a way to protect the environment and wildlife, maintaining the rural community alive with raising the quality of life, ensuring the same conditions for farmers in all member states, fighting the global economic crisis, combating climate change, preservation of cultural heritage, achievement and maintenance of self-sufficiency in food. CAP is a consequence of a single economic area and guarantees fair trade, defense of farmers from traffickers, speculators and imported importers, must respect the high standard of the EU, the complete ban on the import of genetically modified products.

All modern challenges to agricultural development require effective measures of agricultural policy (Ristić, Milijić \& Durkalić).The most important reason why agriculture in the EU is more developed and why they are farmers in European countries in a better position than domestic ones, there is the existence of quality communication and cooperation with state institutions. In order to achieve this, it is necessary for agricultural producers to be integrated, that is, to respect the standards of association and cooperation. On the other hand, state institutions should respect good governance standards. Also, Sustainability agricultural principles require changes in the way of thinking and values, where the changes must include global interdependence, life environment management, social responsibility and economic sustainability ( Kostić, Lakićević \& Milićević). 
The Serbian agriculture sector in the past decades, after all the negative challenges that it faced in the past, experienced a serious economic downturn and economic crisis. Recovery of Serbian agriculture and rural development, economic growth and competitiveness of agricultural products, improvement of standards and preservation of the environment, are possible only with the integration and implementation of CPU regulations. In recent years, Serbia has embarked on systemic and structural reforms of the agrarian sector. It has adopted a strategy for agriculture and rural development. It has begun to integrate CAP and harmonize with EU legislation through the financial donation of various funds and programs (SAPARD, IPA, IPARD, etc.). However, it is still confronted with many problems and challenges that undermine agricultural recovery, economic growth and development. There is no doubt that it is one of the most difficult chapters in the EU accession negotiations, it is the chapter of agriculture. The chapter requires a lot of effort, good organization and priority in implementation and harmonization, since more than one-third of all the regulations for accession are precisely from this sector. Bearing in mind the weight and conformity of the CAP and the integration process, as well as the unfavorable situation of the Serbian agrarian sector, a great responsibility is evident in the standardization and acceleration of the process on the path to equal EU membership

In the past period, Serbia started structural reforms of agrarian policy by implementing various strategies and programs and made significant steps. The harmonization of the standardization of the common agricultural policy and agricultural policy of Serbia is not only a condition for membership in the EU. Its application would result in increased production, improved product quality, market competitiveness, increased imports and exports, modernization of equipment and introduction of new technologies, etc. Consequently, there would be an improvement in the socio-economic life, an increase in the standard of the population, the development of the rural environment and the recovery of the country and the Serbian economy as a whole. Various investments and donations have given hope to a Serbian farmer to stay in the countryside and develop his farm and production, nurturing the EU standard and preserving its environment and environment.

\section{Conflict of interests}

The authors declare no conflict of interest.

\section{References}

1. Babović, J. i Tasić, S. (2013). Agroeconomic and rural policy of the European Union [in Serbian: Agroekonomska i ruralna politika Evropske unije]. Fimek, Novi Sad.

2. Development of agriculture in Serbia and European standards [in Serbian: Razvoj poljoprivrede u Srbiji i evropski standardi] (2017), Evropske sveske br. 8

3. European Commission (2010). The Common Agricultural Policy after 2013. Public debate. Summary Report. 
4. European Commission (2018). Serbia 2018 Progress Report, Brussels.

5. Kostić, M., Lakićević, M., \& Milićević, S. (2018). Sustainable tourism development of mountain tourism destinations in Serbia. Economics of Agriculture, 65(2), 843-857. doi:10.5937/ekoPolj1802843K

6. Mihajlović, B. (2011). Agricultural policy of the European Union countries. [in Serbian: Agrarna politika zemalja Evropske Unije], Poljoprivredni portal Agroplod.

7. Mikuš, O., Ramani, D. i Franić, R. (2010). Guidelines for the Common Agricultural Policy of the European Union after 2013. [in Serbian: Smjernice zajedničke poljoprivredne politike Europske Unije nakon 2013. godine] Agronomski glasnik, 72(6), 345-358.

8. Moyer, H. W. (1993). EC Decisionmaking, The MacSharry reforms of the CAP, Mastricht, and the GATT Urugway Round, available at: http://aei.pitt.edu

9. Ristić, L., Milijić, N., Durkalić, D., (2017), Sustainable agricultural development in modern conditions, 7th International Symposium on Environmental and Material Flow Management - EMFM 2017, Technical Faculty in Bor, pp. 83 98, ISBN: 978-86-6305-071-6, Bor.

10. Stead, D. (2007). Common Agricultural Policy. EH.Net Encyclopedia, (Robert Whaples, ed.). available at: http://eh.net/encyclopedia/article/Stead.CAP

11. Stojanović, I., Manić, A. i Nerić, N. (2018). Agrarian Policy and Rural Development of the European Union and Serbia [in Serbian: Agrarna politika i ruralni razvoj Evropske unije i Srbije]. Megabiznis, 2 (1), 117-140.

12. Strategy for Agriculture and Rural Development of the Republic of Serbia for the period 2014-2024 [in Serbian: Strategija poljoprivrede i ruralnog razvoja Republike Srbije za period 2014-2024. godine], "Sl. glasnik RS”, br. 85/2014

13. Vapa Tankosić J. i Stojsavljević M. (2014). EU common agricultural policy and pre-accession assistance measures for rural development. Economics of Agriculture, 61(1), 195-210.

14. Volk, T., Rednak M. i Erjavec, E. (2010). Western Balkan agriculture and agricultural policy - Cross-country overview and comparison.

15. Živadinović, B. i Milovanović, M. (2011). EU Policy Guide - Agriculture [in Serbian: Vodič kroz EU politike - Poljoprivreda], Beograd, Evropski pokret u Srbiji. 